\title{
ARCHEOLOGICKÝ VÝSKUM V MINCOVNI KREMNICA V ROKOCH 2010-2014
}

\author{
KRISTÍNA KUČERÁKOVÁ - JÁN BELJAK
}

\begin{abstract}
Abstrakt: Mincovňa Kremnica, postavená v priestore hradobného systému mesta Kremnica, predstavuje nasledovnika najstaršej mincovne v starom komorskom dvore. Jeden z najstaršich nepretržite produkujúcich podnikov na svete si počas svojej existencie vyžadoval početné prestavby. Posledné úpravy, realizované v rokoch 2010-2014, priniesli okrem pozostatkov novovekých architektúr aj poznatky o stredovekom opevnení mesta Kremnica. Vo východnej časti južného nádvoria, tzv. nového komorského dvora, sa doložil bližšie neurčitelný stredoveký múr. Vo východnom krídle zo záveru 19. storočia boli objavené poškodené murivá mestského opevnenia zo začiatku 15. storočia a torzá veže barbakanu z druhej štvrtiny 16. storočia.
\end{abstract}

Kl'účové slová: vrcholnýstredovek-raný novovek-Kremnica-mincovňa-mestské opevnenie-barbakan.

\section{Fragmentary Architecture Found in the Kremnica Mint during the Excavations in 2010-2014}

Abstract: The Kremnica mint was built within the medieval fortification of the town as a successor of the oldest mint located in the old chamber court. It is one of the oldest establishments in operation in the world. The mint has been rebuilt several times. The latest reconstruction in the years 2010-2014 brought, apart from information about modern-age mint architecture, also a new insight into the medieval fortification of Kremnica. A medieval wall was excavated in the eastern part of the south mint court ("the new chamber court"). Some damaged masonry, part of the medieval fortification erected in the early 15th century, was unearthed in the eastern wing from the end of the 19th century, along with the remains of a barbican from the second quarter of the 16th century.

Key words: high Middle Ages - early modern period - Kremnica - mint - town fortification - barbican.

Pôvodne stredoveké mesto Kremnica sa nachádza v údolí Kremnických vrchov, kadial’ pretekajú Kremnický potok a riečka Bystrica so svojimi prítokmi, ktoré sa vlievajú do Hrona.

Podla názoru niektorých odborníkov sa zlato t’ažilo v Kremnici zrejme už pred obdobím vrcholného stredoveku (Horák 1965, 25). O exploatovaní kremnického zlatonosného ložiska pred 14. storočím však zatial' neexistujú žiadne priame údaje. Domnienku o jeho skoršej t’ǎ̌be naznačuje neskororománska Rotunda sv. Michala z obdobia okolo polovice 13. storočia. Okolo nej sa sústredilo sedem malých osád, z ktorých neskôr vznikla Kremnica (Kazimír a kol. 1978). O staršom pôvode Kremnice azda vypovedá aj správa o Hornej dedičnej štôlni z roku 1385, ktorá mala byt' v tomto období už opustená (Dvořáková-Husovská 1988, 139; Šášky 1968, 7).

Za dôvod vzniku stredovekého banského mesta je vo všeobecnosti považovaná miestna rudná základňa s obsahom drahých kovov. Ide o rudné žily v obvodoch obcí Kremnica a Kremnické Bane, pričom sa ich výbežky tiahnu aj do d’alších okolitých obcí (Horák 1965, 24). Ďalšími predpokladmi pre vznik osídlenia boli pomerne silné vodné toky a hory bohaté na drevo a kameň.

Kremnica bola konštituovaná ako mesto sedemnásteho novembra 1328, pričom sa tento dátum viaže aj so založením miestnej mincovne. Privilégium vydal král' Karol Róbert z Anjou pre všetkých hostí, ktorí sa v meste už usadili, alebo sa v budúcnosti usadia (Horák 1965, 23), pričom sa mali riadit' právom stanoveným v Kutnej Hore. V prvej tretine 14. storočia král' konsolidoval menové pomery Uhorska a zaviedol zlaté mince. Z historických prameňov nie je zrejmé, kedy sa začali v mincovni produkovat' kremnické dukáty, ich razba sa však spomína v zmluve o prenájme kremnickej komory z marca 1335 (Chmelík-Kianička-Kamhalová 2005, 24). Kremnica sa ako dôležitá finančno-politická základňa stala sídlom územne najväčšej Hornouhorskej banskej a mincovej komory, do ktorej patrilo územie dvanástich stolíc na čele s komorským grófom (Dvořáková-Husovská 1988, 140). Spolu s d’alšími deviatimi komorami mala na starosti správu baní a produkciu peňazí (Paulinyi 1965, 182). Prvým známym komorským grófom bol Leopold, ktorý mal za úlohu realizovat' snahy a opatrenia král'a o tzv. „vel'kú mincovnú reformu“ medzi rokmi 1323-1342 (Horák 1965, 29-30). 
Mincovňa sa spočiatku nachádzala severne od centrálneho námestia, v starom komorskom dvore pod kopcom Revolta v doline Colner (pri sútoku potokov Novej a Starej doliny), kde ležala pôvodná banícka osada Cremnychbana (Lamoš 1969, 38). Ide o tzv. Silberstreckwerhk No 1, ktorý bol využívaný ešte v roku 1889 ako Dolná valcovňa (Chmelík-Kianička-Kamhalová 2005,30). Ked’že sa na vonkajšom obvode domov na námestí vybudovali hradby (vznikli pravdepodobne niekedy v prvej štvrtine 15 . storočia; obr. 1), objekty mincovne boli ešte pred požiarom v roku 1434 (Horák 1965, 43-44) premiestnené dovnútra opevnenia obklopujúceho jadro mesta, kde sa nachádzajú doteraz. Vzhl'adom na bohatý arzenál zbraní v objekte možno hovorit' o určitom druhu samostatnej pevnosti v intraviláne opevneného mesta (Kazimír a kol. 1978, 48).

Podl'a najstaršieho súpisu z polovice 16. storočia možno predpokladat', že už v 15. storočí mala mincovňa 30 miestností, postavených okolo centrálneho dvora. Najstaršou a najvzácnejšou gotickou čast’ou stavby je tzv. nový komorský dvor v juhovýchodnej časti mincovne. V západnom trakte sa nachádza renesančná hala s toskánskymi stípmi v dvoch radoch. Mincovňa mala pôvodne charakter obrannej bašty, zabudovanej do mestských hradieb (Chmelík-KianičkaKamhalová 2005, 16-17). Najstaršia gotická čast’ mincovne bola neskôr viackrát prestavaná. Ide o renesančné i mladšie stavebné úpravy, ktorými sa budova d’alej rozširovala.

Napr. v roku 1601 kúpila mincovňa jeden z domov pri Hornej bráne a k d’alšiemu rozšíreniu priestorov došlo v 18. storočí. V roku 1780 sa zbúrala veža mestského opevnenia za budovou lúčobne. V období medzi rokmi 1802-1804 si vel'kovýroba mincí vyžiadala d’alšie rozšírenie priestorov, preto sa nové technológie nainštalovali do susedného Pewerlliho domu a na dvore starej valcovne na predmestí sa postavila provizórna razobňa. Stavebné úpravy skúšobne sa uskutočnili v roku 1850 kvôli novému zariadeniu na skúšanie drahých kovov (Chmelík-Kianička-Kamhalová 2005).

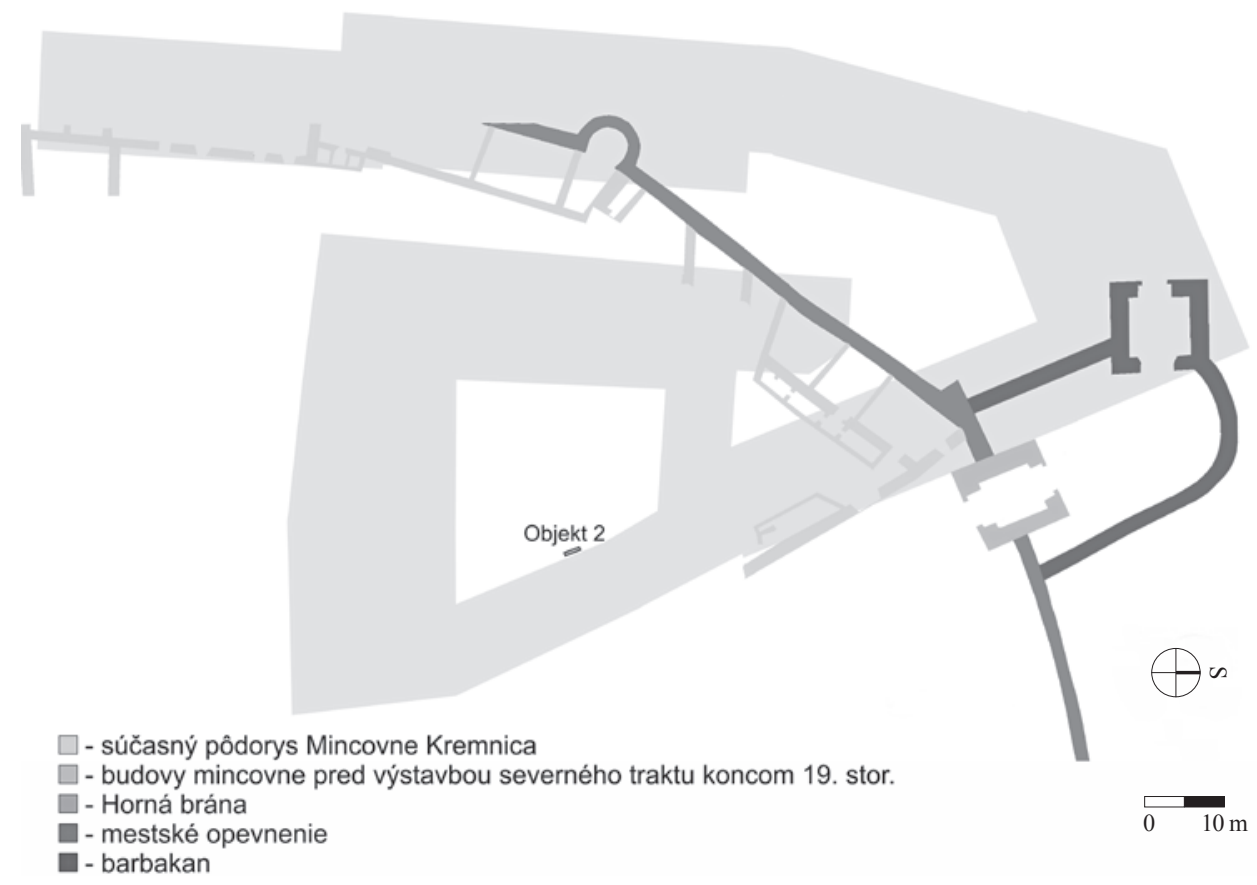

Obr. 1. Kremnica - Mincovňa Kremnica. Súčasný pôdorys mincovne prekrytý plánom mestského opevnenia a starších budov továrne. Zdroj plánu Krajský pamiatkový úrad Banská Bystrica.

Abb. 1. Kremnitz - Kremnitzer Münzhaus. Gegenwärtiger Grundriss des Münzhauses mit drübergelegter Planskizze der Stadtbefestigung und der älteren Gebäude des Münzhauses. Quelle der Planskizze Kreisdenkmalamt Banská Bystrica. 
Najstarší zachovaný pôdorys mincovne v Kremnici pochádza z roku 1767 a pri jeho porovnaní s plánom z roku 1855 je možné identifikovat' stavebné úpravy v zmienenom období, ktoré však neboli vel'mi výrazné. Po rakúsko-uhorskom vyrovnaní v roku 1867 nepovažovali uhorské úrady kapacitu mincovne za dostačujúcu a ich zámerom bola jej modernizácia. K uskutočneniu rekonštrukcie nakoniec došlo aj medzi rokmi 1882-1889. S mestom a súkromníkmi sa dohodol odpredaj štyroch domov, ktoré boli zbúrané, rovnako ako Horná brána a celý úsek hradieb od františkánskej veže smerom na sever (obr. 2). Výraznejšie stavebné úpravy z obdobia 20. storočia pochádzajú z obdobia po 2. svetovej vojne (Chmelík-Kianička-Kamhalová 2005).

Najstarší záchranný archeologický výskum v priestore mincovne je známy z polovice 20. storočia (Križanová 1947). Nálezy sú datované do 13.-14. storočia. Archeologický výskum tu začiatkom 21. storočia viedol aj doc. PhDr. Jozef Hoššo, CSc. Záchranný archeologický výskum v súvislosti s prestavbami mincovne realizovali v rokoch 2010 a 2013-2014 pracovníci Archeologického ústavu SAV J. Beljak a K. Kučeráková (Beljak-Kučeráková 2010; 2014).

\section{Vyhodnotenie}

Žigmund Luxemburský nariadil tzv. malým dekrétom v roku 1405 král’ovským mestám vystavat' mestské opevnenia. V oblasti banských miest na tento podnet zareagovala len Kremnica (Miňo 2011), kde sa hradby budovali zrejme medzi rokmi 1405-1426. Za horné ohraničenie obdobia výstavby mestského opevnenia sa rok 1426 považuje z dôvodu, že od tohto dáta sa už v mestských účtovných knihách nespomínajú žiadne väčšie výdavky. Ked’že mincovňa už v roku 1434 fungovala v novom komplexe, možno predpokladat', že už pri výmere námestia sa počítalo s jej ochranou za hradbami (Oriško 1984, 22). Tento predpoklad potvrdzuje i smerovanie ich pril’ahlého úseku vedúceho k Hornej bráne, ako aj plány a veduty mesta. Na základe charakteru kremnických mestských hradieb však nemožno celkom vylúčit, že vznikli už v 14. storočí (Oriško 1984, 79). Ide totiž o jednoduchý gotický typ fortifikačného stavitel'stva používaný od druhej polovice 14. storočia, ktorý sa však nezmenil ani v nasledujúcom období.

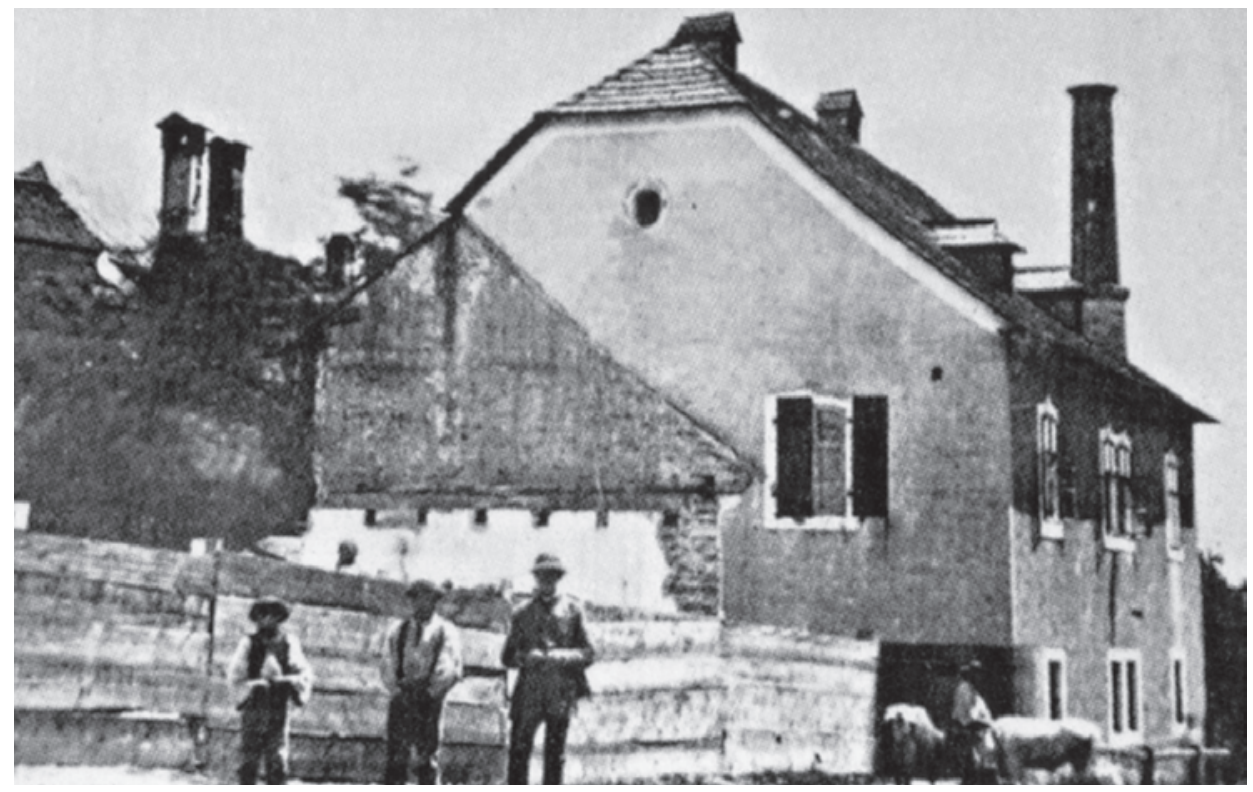

Obr. 2. Kremnica. Uvol’nená plocha po zbúraní mestských hradieb a stará lúčobňa v juhozápadnej časti továrne pred výstavbou nového západného krídla mincovne (okolo roku 1882). Podl’a Chmelík-Kianička-Kamhalová 2005, 21.

Abb. 2. Kremnitz. Freigewordene Fläche nach Abriss der Stadtmauer und das alte Scheidehaus im Südwestteil des Werks vor dem Umbau des neuen Westflügels des Münzhauses (um 1882). Nach Chmelík-Kianička-Kamhalová 2005, 21. 
V účtovnej knihe Banskej Bystrice z devät'desiatych rokov 14. storočia sa spomínajú výdavky na stavebné aktivity v Kremnici. Zo zápisu však nie je jasné, o aký druh stavby išlo. Do úvahy pripadá opevnenie kvôli ochrane komorských budov a zariadení, ktoré však stáli nielen v meste, ale aj na hrade. Za predpokladu, že išlo o výstavbu mestských hradieb, by to znamenalo, že v tom čase už na námestí stál nový komorský dvor s mincovňou. V súčasnosti však k tejto otázke nemožno zaujat' jednoznačné stanovisko (Haas Kianička 2014, 240-241). V roku 1441 sa fortifikácia prvýkrát spomína v záznamoch týždenných výdavkov mesta v súvislosti s drobnými položkami na jej úpravu (Oriško 1984, 79; Śášky 1968, 53).

Charakteristikou kremnického mestského opevnenia a jeho komparáciou vo vzt’ahu k d’alším stredovekým banským mestám sa zaoberal M. Miňo (2011). Fortifikácia podl'a neho pozostáva z lomového kameňa a potočných obliakov miestnej proveniencie a dosahuje výšku $12 \mathrm{~m}$. Zvonku bola päta hradby chránená potokmi (južná a západná čast') alebo priekopou (východná čast'). Drevená ochodza, prechodná okolo celého mesta, zabezpečovala prístup k štrbinovým a kl'účovým striel'ňam a bola prekrytá šindlovou strieškou. Hradby neboli nikdy zosilnené parkanom (Oriško 1984, 22).

V severnej časti boli predížené kvôli plynulému prepojeniu na mestský hrad (Hoššo 1983). Ich súčastou bolo devät' pravidelne rozmiestnených otvorených hranolových flankovacích a valcových/polovalcových (Oriško 1984, 22) bášt, ohraničujúcich kurtiny. Kruhová bašta v severozápadnom nároží mestského opevnenia bola zbúraná pri rozširovaní mincovne na konci 19. storočia (Oriško 1984, 78-79; obr. 2). Mestská fortifikácia zahŕňala tiež Dolnú, Hornú a Bystrickú bránu. Opevnením sa vymedzilo takmer obdížnikové námestie, obklopené 38 parcelami s domami. Zdokumentované je na lavírovanej perokresbe mesta z roku 1742 od B. Maylera, ktorá bola vložená do františkánskej kroniky. Nachádza sa v rímsko-katolíckej fare v Kremnici (napr. Horák 1965, obr. 85; Oriško 1984, obr. 42).

Počas archeologického výskumu v rokoch 2010-2014 sa v Mincovni Kremnica podarilo odkryt' pozostatky objektov, ktoré boli súčastou mestského opevnenia. Základové torzo stredovekej fortifikácie sa doložilo v miestnosti A (múr 5). Ide o koncový úsek hradby západne od jeho napojenia na Hornú bránu (obr. 4). Múr ohraničoval severozápadnú čast’ mincovne, kde sa cípovito zbiehalo jej západné a východné krídlo a kde boli situované komory s krmivom a sklad dreva. Torzo objavené v rokoch 2013-2014 pôvodne ohraničovalo zo severozápadnej strany mincovne maštale. Východne od nájdenej architektúry stál výjazd z druhého, severného nádvoria, vedúci k južnej časti Hornej brány.

Táto čast' opevnenia bola asanovaná v roku 1872 spolu s Hornou bránou (obr. 2) kvôli zintenzívnenej doprave, čo následne umožnilo prestavbu továrne medzi rokmi 1882-1889.

Situovanie brán v kremnickom opevnení určovalo hlavné komunikačné osi mesta, pričom Horná a Dolná brána vytyčovali severojužnú cestu z Pohronia cez Turiec na Považie (Dvořáková-Husovská 1988, 141). V severnej časti mesta ústila do dnešnej Kutnohorskej ulice, kde sa na budove s popisným číslom 22 nachádza kamenný reliéf baníckych a minciarskych emblémov, premiestnený zo zrútenej Hornej brány (Šášky 1968, 57). Vstupovalo sa ňou do mestského opevnenia smerom od starého komorského dvora.

Horná brána mala podobný charakter ako dodnes stojaca Dolná brána. Ide o vežový hranolový objekt s prejazdom uzavretým zvonku spúšt’acou mrežou a zvnútra vrátami (Fillová 1986, 37). Nenachádzala sa tu teda žiadna forma padacieho mosta, čo je prvok spoločný pre všetky (aj mladšie) mestské brány banských miest (Miňo 2011, 291-292).

Podobne ako príslušná čast' opevnenia, aj Horná brána bola v roku 1872 zbúraná a následne koncom 19. storočia jej priestor zabrala mincovňa. Severojužná mestská komunikácia sa po jej zrútení a strhnutí pril'ahlého úseku hradieb presunula do hradnej priekopy (Dvořáková-Husovská 1988, 145).

Jej podoba sa zachovala na olejomal'be akademického maliara Vojtecha Angyala, ktorý rozhodným spôsobom zakročil proti zrúteniu Dolnej brány, a tiež na dobových fotografiách (obr. 3, 4). Obrázok 4 zachytáva mestskú bránu pri pohl’ade z juhu (od námestia) a napravo (východ) od brány neskorogotický dom na Kutnohorskej ulici číslo 4. Na fotografii je zachytená ešte jeho neskorobaroková fasáda s rizalitom na pilieroch, odstránená začiatkom 20. storočia. Gotické sieňové domy 


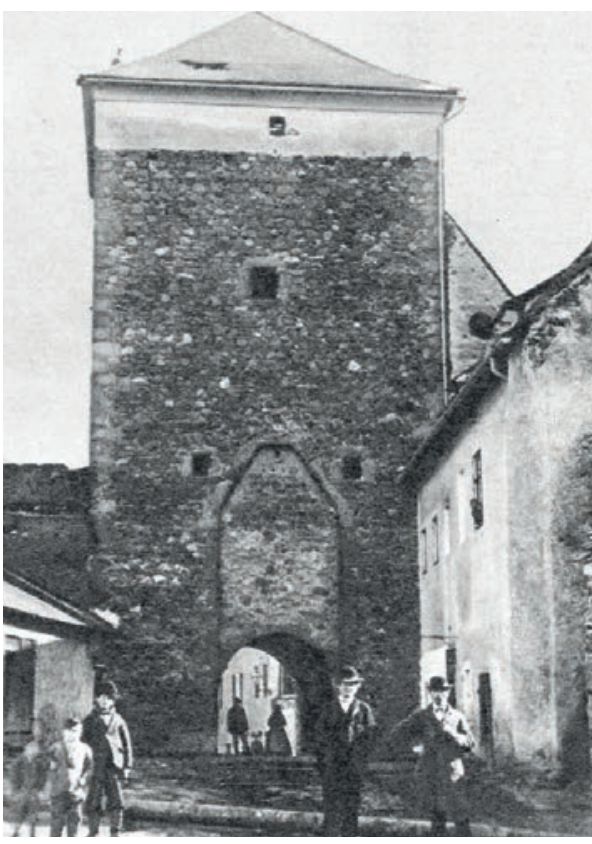

Obr. 3. Kremnica. Horná brána mestského opevnenia na dobovej fotografii z druhej polovice 19. storočia. Pohl'ad na juh. Podl'a Oriško 1984, obr. 14.

Abb. 3. Kremnitz. Oberes Tor der Stadtbefestigung auf einer zeitgenössischen Fotografie aus der zweiten Hälfte des 19. Jahrhunderts. Blick nach Süden. Nach Oriško 1984, Abb. 14.

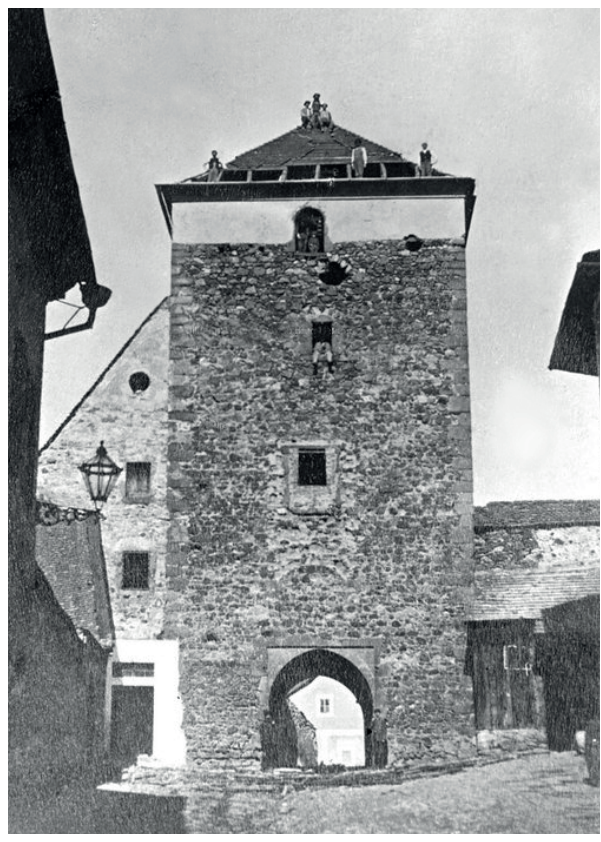

Obr. 4. Kremnica. Fotografia s vyobrazením Hornej mestskej brány. Pohl'ad na sever. Zdroj kópie Múzeum mincí a medailí Kremnica, elektronická zbierka D. Kianičku.

Abb. 4. Kremnitz. Fotografie mit Darstellung des Oberen Stadttors. Blick nach Norden. Quelle des Abzugs Münzenund Medaillenmuseum Kremnica, elektronische Sammlung D. Kianička.

v Kremnici datované do 14. storočia si udržali svoju podobu len s menšími renesančnými úpravami, realizovanými do 17. storočia. Ťažisko novostavieb sa následne presunulo pred mestské brány, kde vznikli meštianske, najmä remeselnícke domy (avšak na staršom základe; Oriško 1984, 52).

Priamo za domom na Kutnohorskej ulici číslo 4 vedie východným smerom línia mestského opevnenia k mestskému hradu, na ktorej je zachytená drevená pavlač. Vl’avo (západne) od Hornej brány sa nachádza ukončenie severného traktu mincovne, datovaného od roku 1434 až do začiatku 16. storočia, kde na vonkajšom líci vidno kamenné konzoly, ktoré sú zachované dodnes. Od nich smerom k bráne vedie východný múr mincovne, ohradzujúci kurín, vodný zdroj a stajne, ktorý ústi k budove pristavanej k západnému múru Hornej brány.

Jej zvyšky sa doložili už archeologickým výskumom pod vedením Jozefa Hošša na Kutnohorskej ulici v exteriéri východnej steny mincovne, kde je v súčasnosti naznačená na ceste. Počas výskumu v rokoch 2013-2014 sa pri výkopových prácach na Kutnohorskej ulici (pozdĺž východného krídla mincovne) nepodarilo zachytit’ žiadnu stredovekú architektúru, ani podobne datované hnutel’né nálezy. Doložil sa však úsek hradby vedúci od Hornej brány k severnému cípu budovy. Ide o severovýchodnú čast' múru 5. Našiel sa v miestnosti A, ktorej východný múr sa takmer dotýka miesta, kde bola pôvodne situovaná západná čast' Hornej brány.

Mesto okrem zosilnení mestských hradieb postavilo pred Dolnú aj Hornú mestskú bránu (Hoššo 2007) renesančné barbakany, z ktorých sa zachovalo len predbránie Dolnej brány (Dvořáková-Husovská 1988, 143). Vznikli v čase nebezpečenstva tureckých nájazdov po bitke pri Moháči, kedy mestá reagovali novou vlnou fortifikačných stavieb (Miňo 2011, 294). Kremnický barbakan patrí medzi prvé protiturecké fortifikácie na území Slovenska a svojím základom vychádza ešte z obdobia vrcholného stredoveku. Vznikol bez znalosti italských bastiónových systémov, no napriek tomu už len vzdialene pripomína monumentálnu výstavbu gotického mesta (Oriško 1984, 52). 
Pozostatky veže barbakanu Hornej brány sa doložili počas výskumu v rokoch 2013-2014 (múry 1-3). Ked’že sa zdá, že múr 6 smeroval severne k bráne barbakanu a zároveň má podobnú konštrukciu ako jej doložené torzá (múry 1-3), je pravdepodobné, že predstavuje základové murivo západnej línie predbránia v mieste jeho pripojenia na mestskú fortifikáciu. Uvedené murivá obsahujú totiž na rozdiel od múru 5, ktorý je zvyškom staršieho mestského opevnenia z prvej štvrtiny 15. storočia, okrem lomového kameňa aj vel'ké okruhliaky.

Pohl'ad z interiéru tohto predbránia na severnú fasádu Hornej brány sa dochoval na dobovej fotografii (obr. 3), kde sú v západnej aj východnej časti zobrazené budovy priamo v jeho areáli a ktoré už dnes neexistujú. Zobrazenie budovy za priechodom Hornej brány (severným smerom; obr. 4) naznačuje, že najprv sa búral barbakan a až následne Horná brána. Priestor medzi severným priečelím Hornej brány a predpokladaným severným oblúkom barbakanu je dlhý ca $20 \mathrm{~m}$ a teda existencia prípadnej stavby v tomto priestore sa ukazuje ako nereálna. Možno sa domnievat', že za Hornou bránou vidno dom na križovatke Kutnohorskej ulice severne od mincovne. $\mathrm{Na}$ fotografii sú zachytení pravdepodobne robotníci, ktorí začínajú s rúcaním brány. Okrem uvedeného sa dochovala fotografia búracích prác na veži barbakanu (obr. 5).

K severozápadnej časti mestskej fortifikácie lemujúcej mincovňu bola v exteriéri pristavaná budova, zachytená na obr. 3 a na obr. 4. Jej strecha sa šikmo zvažovala od západného múru Hornej brány západným smerom a z východnej strany zaberala takmer celú jej šírku. Je pravdepodobné, že základy tejto stavby boli počas výskumu v rokoch 2013-2014 objavené v miestnosti B a možno ich stotožnit's múrom 4. Ten predstavuje základ severného múru uvedenej stavby, na ktorý sa napájala d’alšia budova.

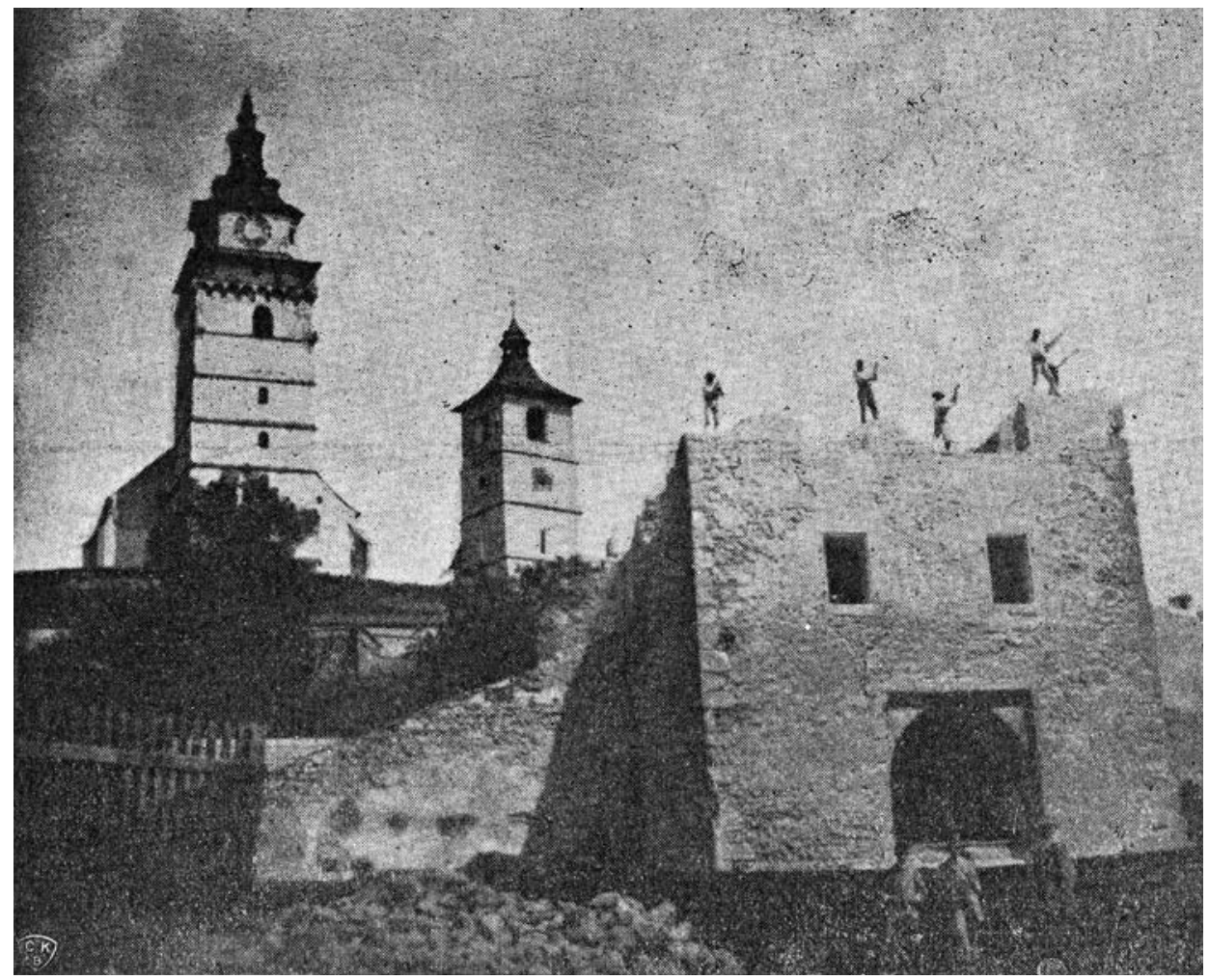

Obr. 5. Kremnica. Búracie práce na bráne barbakanu Hornej brány. Pohl’ad na juhovýchod. Zdroj kópie Múzeum mincí a medailí Kremnica, elektronická zbierka D. Kianičku.

Abb. 5. Kremnitz. Abrissarbeiten am Barbakanentor des Oberen Tors. Blick nach Südosten. Quelle des Abzugs Münzenund Medaillenmuseum Kremnica, elektronische Sammlung D. Kianička. 
Na vedute z roku 1742 (napr. Haas Kianička 2014, obr. 43) nie je v týchto miestach okrem funkčných prvkov mestského opevnenia doložená žiadna budova. Na pôdoryse mincovne z roku 1767 (Chmelík-Kianička-Kamhalová 2005, 18) v priestore, kde bola neskôr postavená budova doložená múrom 4, je s najväčšou pravdepodobnost’ou zachytená bránka pre peších (medzi severným cípom mincovne a západným múrom Hornej brány). Podl’a situácie zdokumentovanej na vyššie uvedených dobových fotografiách však táto bránka už pred prestavbou mincovne medzi rokmi 1882 a 1889 nemohla byt' funkčná. Jej súčastou bol južnejšie situovaný vstup, doložený na obr. 4, ktorý sa na rozdiel od bránky pre peších napája na juhozápadný roh Hornej brány. Na základe vyššie uvedeného možno konštatovat', že predmetná stavba bola postavená po roku 1767 a zanikla počas prestavby mincovne v závere 19 . storočia.

\section{Výskum v rokoch 2013-2014}

V priebehu rokov 2013 a 2014 realizoval Archeologický ústav SAV pod vedením J. Beljaka a K. Kučerákovej záchranný archeologický výskum v priestoroch východného krídla novovekého severného traktu mincovne a na severnom nádvorí (obr. 4; Beljak-Kučeráková 2014). Zároveň boli dokumentované výkopové práce v exteriéri budovy na Kutnohorskej ulici, kde sa situácie z hl'adiska archeológie javili negatívne. Prevažná čast' archeologických nálezov bola odkrytá vo východnom krídle. Tiež sa tu preukázalo vel'ké množstvo recentných zásahov. Okrem zemných prác bola počas trvania stavebných aktivít realizovaná aj rekonštrukcia vybraných architektúr $\mathrm{v}$ exteriéri a interiéri skúmaného priestoru. Ked’že výkopové práce $\mathrm{v}$ mincovni bolo potrebné uskutočnit' len do híbky ca $0,7-1,3 \mathrm{~m}$, potrebnej pre účely prestavby (výmena podláh a inžinierske siete), u žiadneho z doložených murív nebola zachytená základová špára.

Východné krídlo severného traktu mincovne, v ktorom sa odkryli stredoveké nehnutel'né archeologické nálezy, pochádza z obdobia rokov 1882-1889. Objekty mincovne pôvodne (od obdobia pred rokom 1434 až do záveru 19. storočia) kopírovali mestské hradby v severozápadnej časti námestia. Pri jej rozširovaní nové objekty mincovne zabrali klinovitý pozemok medzi bývalou hradbou a potokom a prekonali pôvodnú líniu mestského opevnenia (Chmelík-Kianička-Kamhalová 2005). Z tohto obdobia sa počas archeologického výskumu doložili takmer vo všetkých miestnostiach východného krídla severného traktu mincovne rozšírené základy múrov a pilierov, ktoré podopierali klenby. Rovnako sú datované otvory vetracieho kanála na odvetranie stien prúdiacim vzduchom, ktorý vysúšal vlhké murivo.

Dispozícia jednotlivých miestností pred začiatkom stavebných prác v rokoch 2013-2014 zodpovedá stavu, ktorý vznikol po roku 1918. Pred ním boli miestnosti usporiadané do väčších halových priestorov so stredovými piliermi. Výnimku tvoria miestnosti v južnej časti skúmaného traktu, ktoré boli súčastou chodbových priestorov, napojených na staršiu čast' budovy z obdobia medzi rokom 1434 až 16. storočím. Priečky vybudované po roku 1918 boli pred začiatkom archeologického výskumu zbúrané. Takmer vo všetkých miestnostiach skúmaného traktu sa pred začiatkom archeologického výskumu nachádzala na povrchu betónová podlaha. Vo viacerých priestoroch $\mathrm{v}$ južnej časti sa pod betónom našla podlaha z pravidelne ukladaných kamenných platní, ktorá vznikla po roku 1882. Na všetkých preskúmaných plochách boli odkryté rôzne zásypové a planírkové vrstvy, ktoré pochádzajú z obdobia výstavby danej časti mincovne.

V južnej časti skúmaného priestoru východného krídla budovy sa nachádzala vodná nádrž, ktorú azda reprezentuje z prameňov známy „objekt s prívodom vody“, z južnej strany napojený na kurín. Postavené boli medzi rokmi 1767-1855. Pravdepodobne z rovnakého obdobia, príp. z rokov výstavby severného traktu, pochádza tiež odvodňovací kanál, ktorý viedol východo-západným smerom. O vzniku týchto objektov ešte pred výstavbou severného traktu (1882-1889) svedčí azda aj analógia nájdená pod podlahou Kostola Panny Márie na Štefánikovom námestí v Kremnici, ktorý bol strhnutý v roku 1880 kvôli statickej poruche spôsobenej systémom banských diel pod mestom (Malček-Kučeráková 2011). V skúmanom priestore sa d’alej odkryli najmä pozostatky technologických zariadení a stavebných úprav z 20. storočia. 
V miestnosti A, ktorá sa nachádza v strednej časti východného krídla severného traktu mincovne, sa našli dva múry z obdobia stredoveku (obr. 6, 7). Priestor sa plošne vykopal do híbky približne $90 \mathrm{~cm}$, okrem rezu pozdíž západného múru miestnosti, hlbokého $100 \mathrm{~cm}$. Betónová podlaha tu prikrývala planírku, pravdepodobne z obdobia prestavby budovy na konci 19. storočia. Pod ňou sa doložil stredoveký múr 5, ktorý smeroval približne od severovýchodného rohu k juhozápadnému rohu miestnosti. Architektúra bola v strednej časti poškodená výstavbou betónovej vane a vo východnej a západnej časti výstavbou východného krídla budovy. Jeho zachovaná čast' mala šírku 1,8 m a dížku 7,4 m. Doložila sa do výšky ca 60 cm. Základová špára sa nezachytila. Múr je postavený z väčších neopracovaných lomových kameňov, spájaných maltou. S jeho výstavbou súvisí tmavošedá zásypová vrstva so stredovekými, prevažne keramickými nálezmi, ktorá sa zachytila pri severozápadnom a severovýchodnom okraji zachovaného muriva (obr. 8). Uvedenú architektúru možno interpretovat' ako základ stredovekého múru mestského opevnenia zo 14. storočia a tmavošedá zásypová vrstva so stredovekými nálezmi, ktorá sa našla $\mathrm{v}$ jeho bezprostrednej blízkosti, pochádza z obdobia jeho výstavby. Východne od torza sa táto čast' mestských hradieb napájala na Kutnohorskej ulici na Hornú mestskú bránu.

Okrem uvedeného sa v miestnosti A doložila d’alšia stredoveká architektúra - múr 6. Ide o pozostatok severojužnej orientácie. Nachádza sa severne od strednej časti múru 5. Takisto bol poškodený výstavbou novovekej betónovej vane a pri budovaní skúmaného traktu mincovne. Jeho zachovaná čast' mala šírku $2 \mathrm{~m}$ a bola dlhá len $105 \mathrm{~cm}$. Doložila sa do výšky približne $50 \mathrm{~cm}$, pričom sa neodkryla základová špára. Múr je postavený prevažne z vel'kých okruhliakov a z menších neopracovaných lomových kameňov, spájaných maltou.

Obr. 6. Kremnica - Mincovňa Kremnica. Súčasný pôdorys mincovne prekrytý plánom mestského opevnenia a starších budov mincovne, spolu s lokalizáciou murív odkrytých v rokoch 2013-2014. Zdroj plánu Krajský pamiatkový úrad Banská Bystrica.

Abb. 6. Kremnitz - Kremnitzer Münzhaus. Gegenwärtiger Grundriss des Münzhauses mit drübergelegter Planskizze der Stadtbefestigung und der älteren Gebäude des Münzhauses sowie Lokalisierung der in den Jahren 2013-2014 freigelegten Mauern. Quelle der Planskizze Kreisdenkmalamt Banská Bystrica.
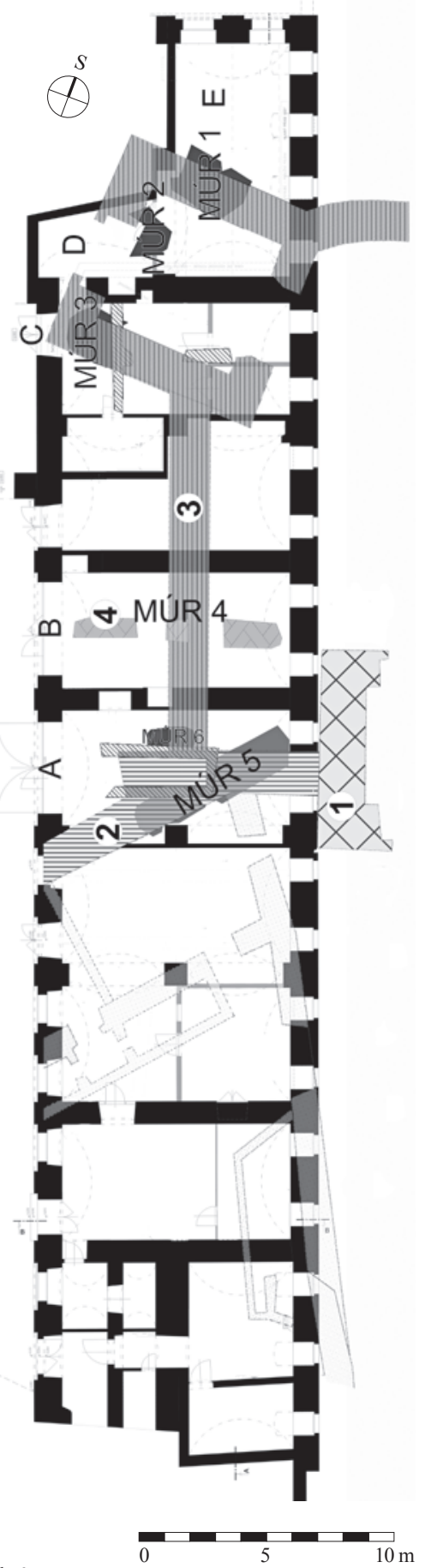

1 - Horná brána

2 - mestské opevnenie

3 - barbakan

4 - pravdepodobne torzo zástavby v exteriéri mestského opevnenia 


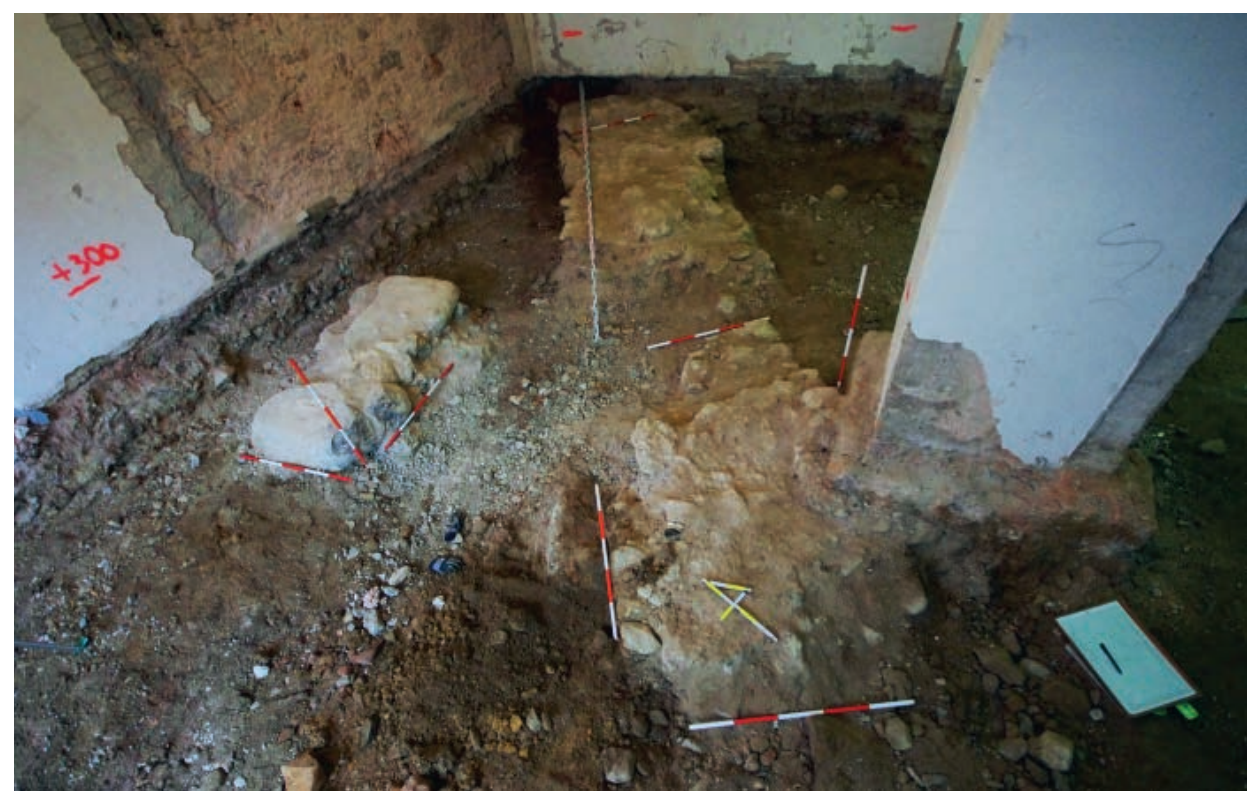

Obr. 7. Kremnica - Mincovňa Kremnica. Výskum v rokoch 2013-2014. Miestnost’ A, pohl’ad od juhozápadu. Vpravo múr 5 - mestská hradba, vl’avo múr 6 - západný múr barbakanu. Foto K. Kučeráková.

Abb. 7. Kremnitz - Kremnitzer Münzhaus. Grabung von 2013-2014. Raum A, Blick von Südwest. Rechts Mauer 5 - Stadtmauer, links Mauer 6 - Westmauer der Barbakane. Foto K. Kučeráková.

Počas výstavby bol zapustený do žltého ílovitého podložia. Múr 6 predstavuje základové murivo západného múru barbakanu, pravdepodobne z druhej štvrtiny 16 . storočia.

Ďalšia stredoveká architektúra pochádza z miestnosti B, ktorá leží severne od miestnosti A a preskúmala sa do híbky približne $90 \mathrm{~cm}$. Pod betónovou podlahou sa tu našlo žlté ílovité podložie, miestami prestúpené premiešanou zásypovou vrstvou. V juhozápadnom rohu miestnosti sa odkrylo tehlové technologické zariadenie z 20. storočia s vaňami s betónovým poterom. Tento objekt sčasti prekrýval múr 4 (obr. 6), ktorý bol na dvoch miestach porušený a tvoril tak tri samostatné bloky (obr. 9). Postavený bol z lomového kameňa rôznych rozmerov. Východný blok múru 4 mal rozmery $1,7 \times 1,3 \mathrm{~m}$. Jeho doložená výška je $55 \mathrm{~cm}$. Najmenší, stredný blok múru má rozmery $1,1 \times 1 \mathrm{~m}$ a jeho zdokumentovaná výška je $50 \mathrm{~cm}$. Západný blok muriva má rozmery $1,2 \times 2,7 \mathrm{~m}$ a doložil sa do výšky $60 \mathrm{~cm}$. Jeho základová špára pri výkopových prácach nebola zachytená. Múr možno interpretovat’ ako severný základ budovy postavenej po roku 1767, ktorá bola zrejme vybudovaná v priestore niekdajšej bránky pre peších medzi severným cípom mincovne a západným múrom Hornej brány. Na múr 4 sa bezprostredne napájala d’alšia budova a teda tento priechod bol v čase stavby múru 4 pravdepodobne znefunkčnený.

V severnej časti skúmaného východného krídla sa do híbky približne $90 \mathrm{~cm}$ preskúmala miestnost' C. Ide o priestor rozdelený priečkami datovanými po roku 1918, ktoré boli pred začiatkom stavebných prác zbúrané. Pod betónovou podlahou sa tu nachádzali rovnaké vrstvy ako v miestnosti B. Do geologickej vrstvy tu boli vsadené dve betónové vane s tehlovým obložením, ktoré predstavujú pozostatky technologického zariadenia. Na severnú betónovú vaňu sa pripájal múr D, ktorý pozostával z dvoch samostatných častí. Pochádza z obdobia po výstavbe predmetného priestoru. Jeho západná čast' so severojužnou orientáciou prekrývala a poškodila pozostatky stredovekej architektúry - múru 3, ktorý sa nachádza v severozápadnej časti miestnosti (obr. 6,10$)$. Pozostáva z väčších a menších lomových kameňov, spájaných maltou. Jeho rozmery sú 2,4 × 3,1 m a jeho maximálna výška doložená pri archeologickom výskume dosahuje približne $40 \mathrm{~cm}$. Základová špára múru 3 nebola v preskúmanej híbke zachytená. Ide o základové murivo, konkrétne juhozápadné nárožie veže barbakanu z druhej štvrtiny 16. storočia. 

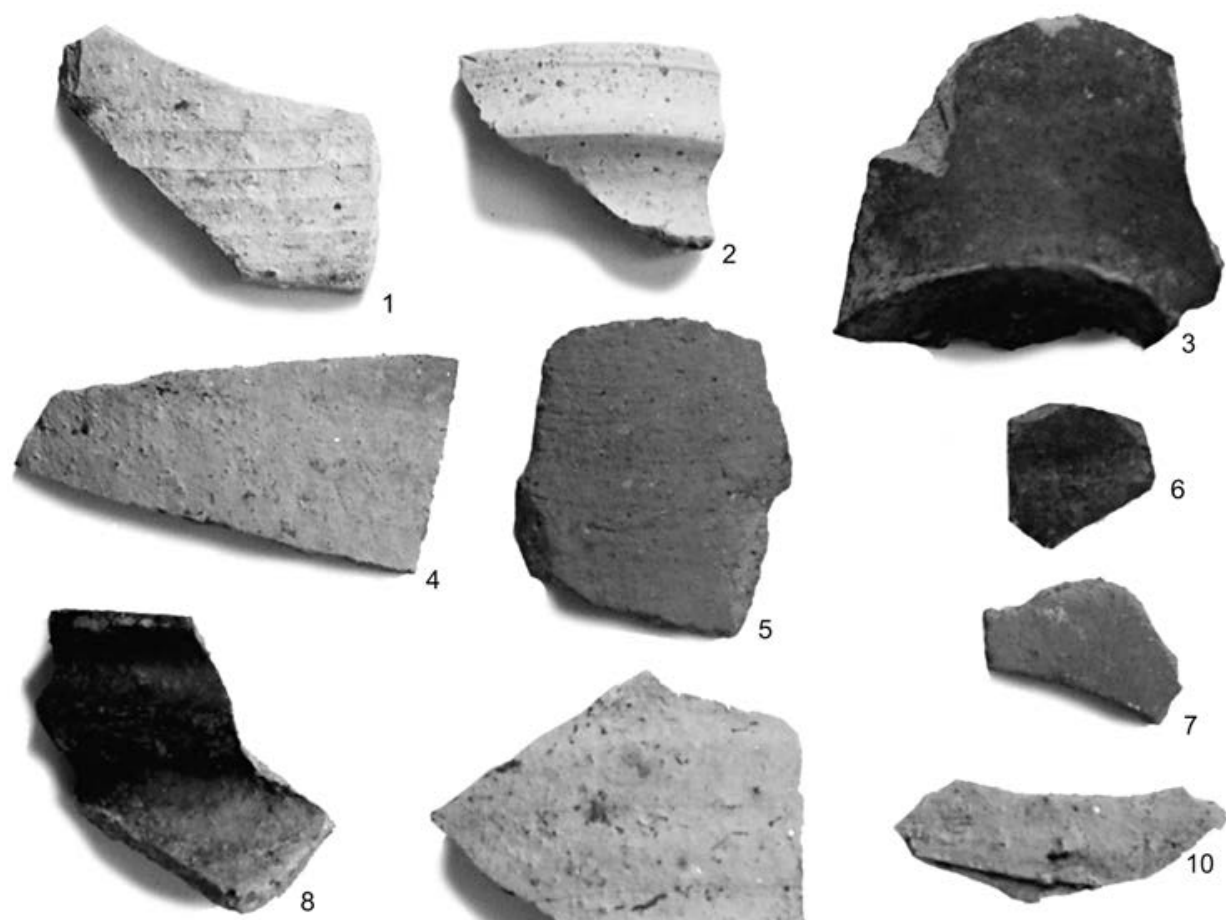

5
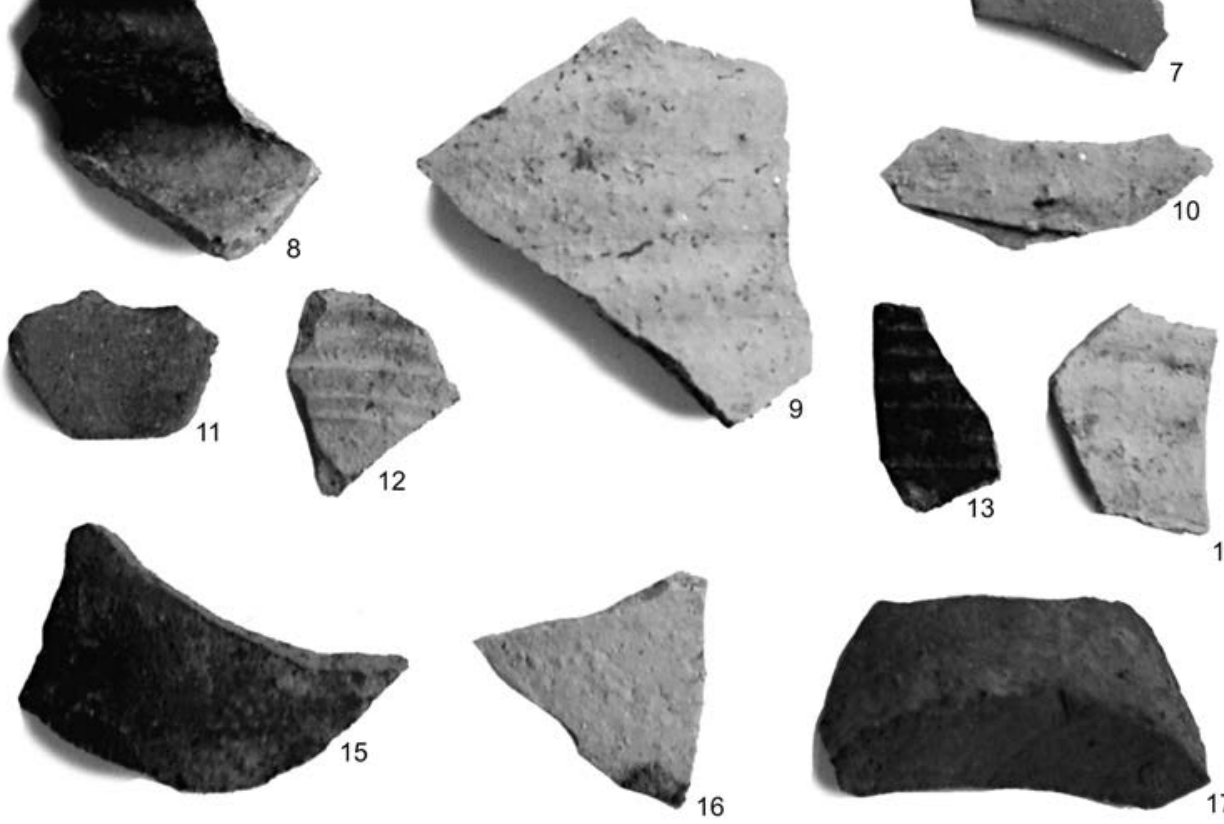

Obr. 8. Kremnica - Mincovňa Kremnica. Miestnost’ A. Výber stredovekej keramiky z tmavošedej zásypovej vrstvy múru 5. Foto K. Kučeráková.

Abb. 8. Kremnitz - Kremnitzer Münzhaus. Raum A. Auswahl mittelalterlicher Keramik aus der dunkelgrauen Verfüllungsschicht von Mauer 5. Foto K. Kučeráková.

V najsevernejšej časti skúmaného východného krídla mincovne sa torzá stredovekej architektúry objavili v miestnostiach D a E, ktoré boli po roku 1918 oddelené priečkou, odstránenou pred začiatkom výkopových prác v roku 2013. Tento priestor sa znižoval do híbky ca $95 \mathrm{~cm}$. Pod betónovou podlahou sa $\mathrm{v}$ juhozápadnej časti miestnosti E pri múre 1 a múre 2 nachádzala vrstva tehlovej drviny prikrývajúca žlté ílovité podložie. Doň boli okrem početných recentných zásahov vsadené štyri kvadratické betónové vane. Po odstránení najjužnejšie položenej vane sa podarilo odkryt' zvyšky stredovekej architektúry (obr. 6). Severnejšie uložený múr 1 z lo- 
mového kameňa spájaného maltou sa nachádza pri západnom múre miestnosti E (obr. 11). Má rozmery $2,2 \times 3,1 \mathrm{~m}$ a jeho maximálna zdokumentovaná výška bola $50 \mathrm{~cm}$. Múr je orientovaný smerom zo severozápadu na juhovýchod. Ďalším dokladom stredovekej zástavby je múr 2, ktorý čiastočne zasahuje aj do miestnosti D (obr. 12). Táto architektúra bola takisto postavená z lomového kameňa spájaného maltou, sú v nej však zabudované aj vel'ké okruhliaky. Jej rozmery sú $2,2 \times 2 \mathrm{~m}$ a jeho maximálna doložená výška je takmer $70 \mathrm{~cm}$. Oba múry boli výrazne poškodené výstavbou severného traktu mincovne a priečok medzi miestnostami a takisto aj betónovými vaňami. Múr 1 predstavuje základové murivo severnej steny veže barbakanu a múr 2 predstavuje základové murivo jej západnej steny. Nepravidelný tvar múru 2 indikuje okrem neskorších stavebných úprav azda prestavbu, resp. stabilizáciu západného vstupu do veže. Barbakan je datovaný do druhej štvrtiny 16. storočia a jeho zánik sa spája s obdobím pred výstavbou severného traktu mincovne (medzi rokmi 1882-1889).

Ďalším preskúmaným priestorom bolo severné nádvorie. Zemné práce boli najprv sústredené v štrnástich sondách pätiek pre novopostavenú halu. Skúmali sa do maximálnej híbky $1,7 \mathrm{~m}$. V nich a aj v d’alších miestach nádvoria sa pod súčasnou kamennou podlahou našlo štrkové lôžko, prekrývajúce planírovacie vrstvy, pod ktorými sa miestami zdokumentovalo aj žlté ílovité podložie. Okrem uvedeného sa našlo aj niekol'ko d’alších novovekých objektov, ktoré zrejme súvisia s prestavbou mincovne koncom 19. storočia. V sonde pätky 13, ktorá sa nachádzala v južnej časti nádvoria pri kotolni, sa v profile našli sekundárne využité, profilované kamenné architektonické články. Zrejme pochádzajú z ostení okien (obr. 13).

\section{Výskum v roku 2010}

Pod vedením J. Beljaka sa v roku 2010 realizoval výskum vo východnej časti južného nádvoria z dôvodu uloženia pätiek pre strojné zariadenia kováčne a realizovania výkopov pre uloženie

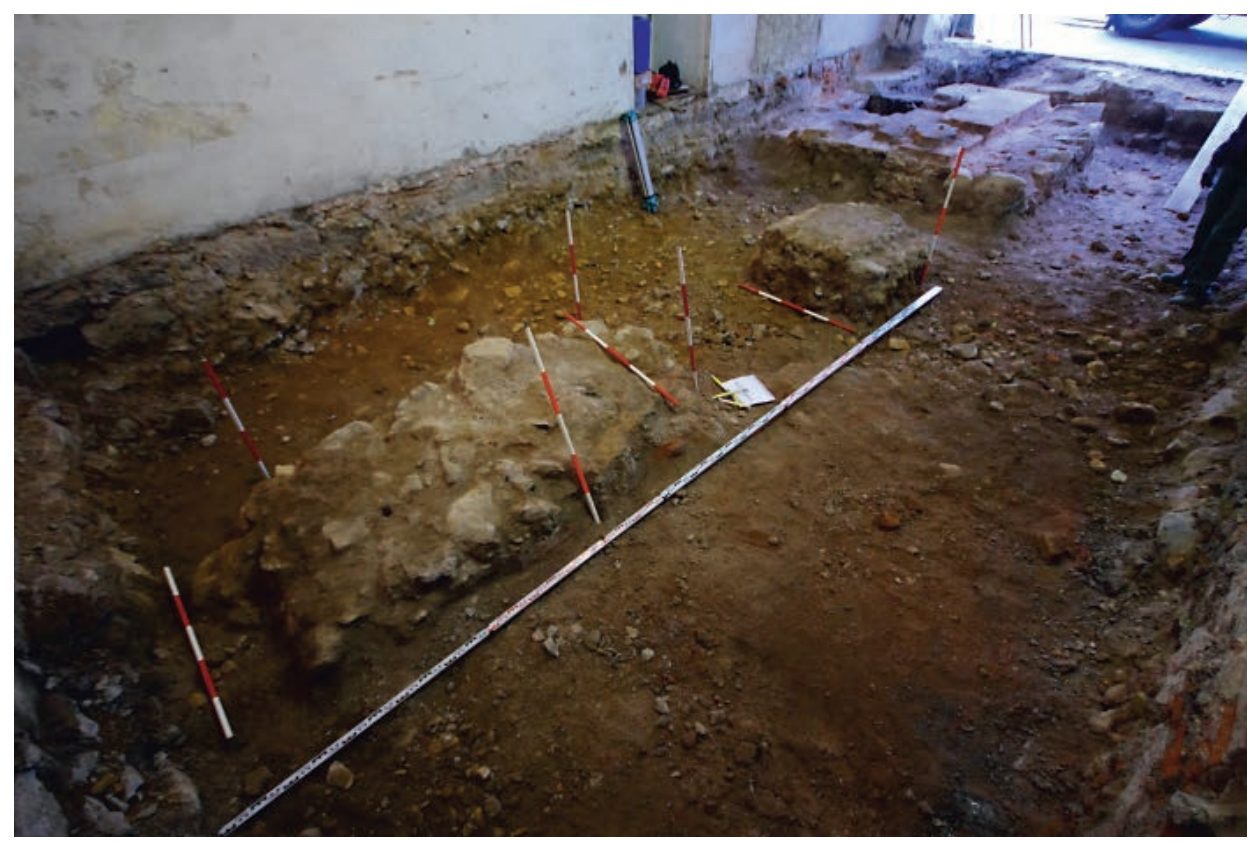

Obr. 9. Kremnica - Mincovňa Kremnica. Výskum v rokoch 2013-2014. Miestnost' B (zástavba v juhozápadnej časti barbakanu), pohl'ad zo severovýchodu. Múr 4. Foto K. Kučeráková.

Abb. 9. Kremnitz - Kremnitzer Münzhaus. Grabung von 2013-2014. Raum B (Bebauung im Südwestteil der Barbakane), Blick von Nordosten. Mauer 4. Foto K. Kučeráková. 


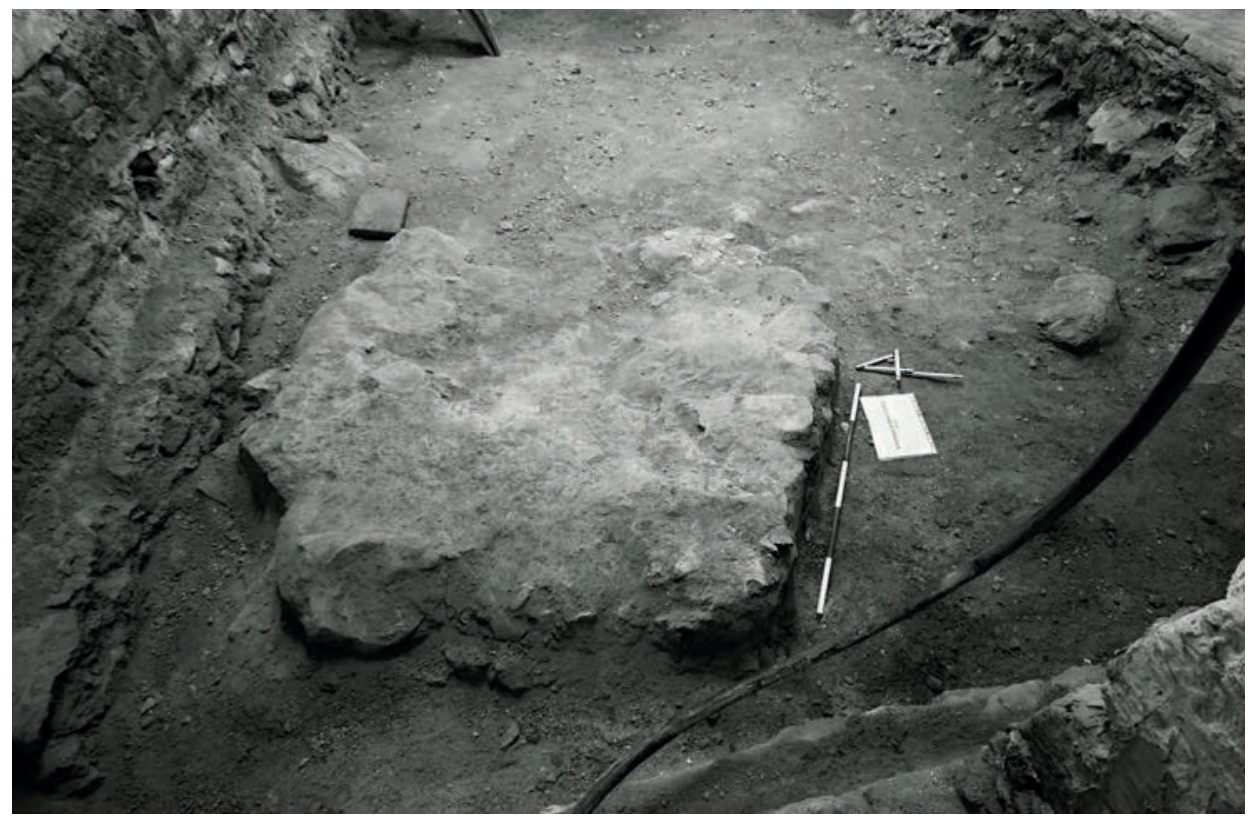

Obr. 10. Kremnica - Mincovňa Kremnica. Výskum v rokoch 2013-2014. Miestnost' C, pohl’ad zo západu. Múr 3 (juhozápadné nárožie veže barbakanu). Foto K. Kučeráková.

Abb. 10. Kremnitz - Kremnitzer Münzhaus. Grabung von 2013-2014. Raum C, Blick von Westen. Mauer 3 (Südwestecke des Barbakanenturms). Foto K. Kučeráková.

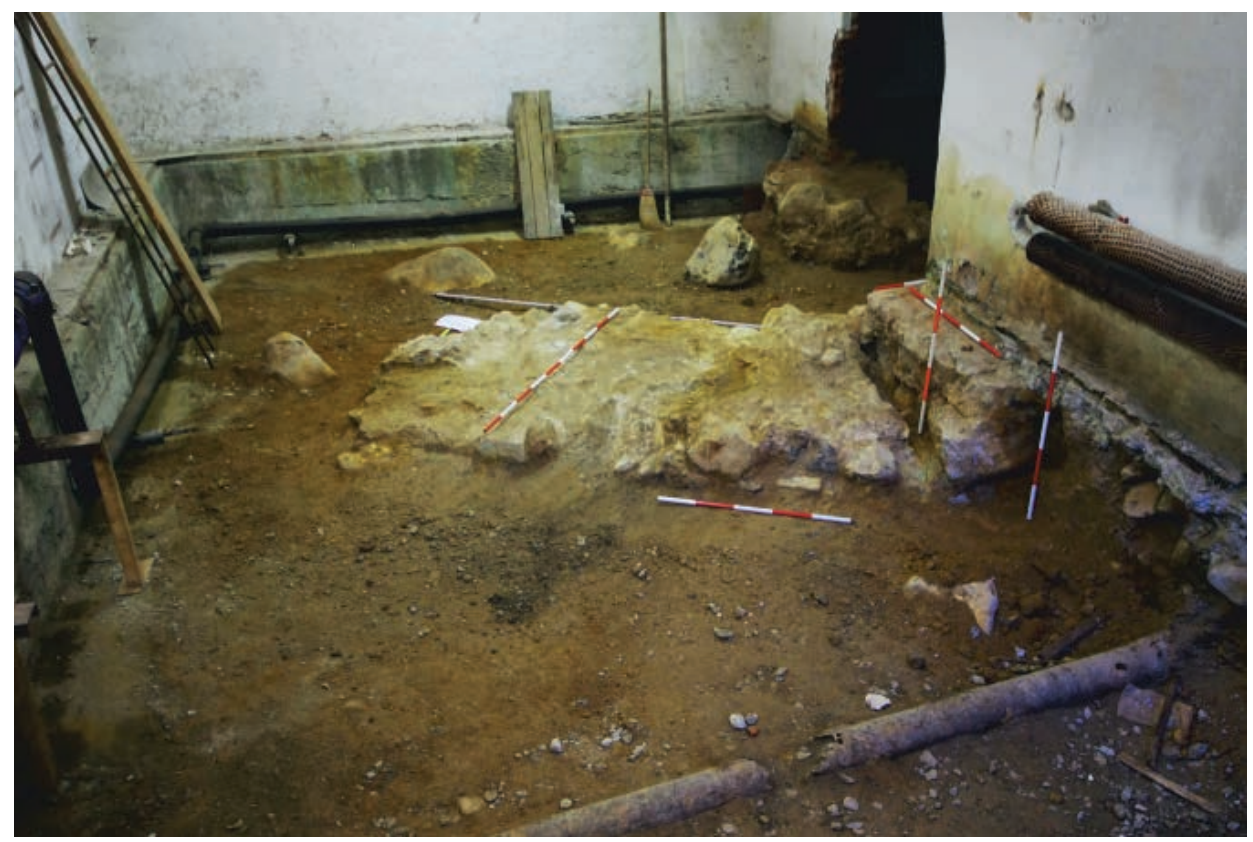

Obr. 11. Kremnica - Mincovňa Kremnica. Výskum v rokoch 2013-2014. Miestnost' D/E, pohl'ad zo severovýchodu. Múr 1 (v popredí) a múr 2 (v pozadí; základové murivo veže barbakanu). Foto K. Kučeráková.

Abb. 11. Kremnitz - Kremnitzer Münzhaus. Grabung von 2013-2014. Raum D/E, Blick von Nordosten. Mauer 1 (im Vordergrund) und Mauer 2 (im Hintergrund; Fundamentmauerwerk des Barbakanenturms). Foto K. Kučeráková. 


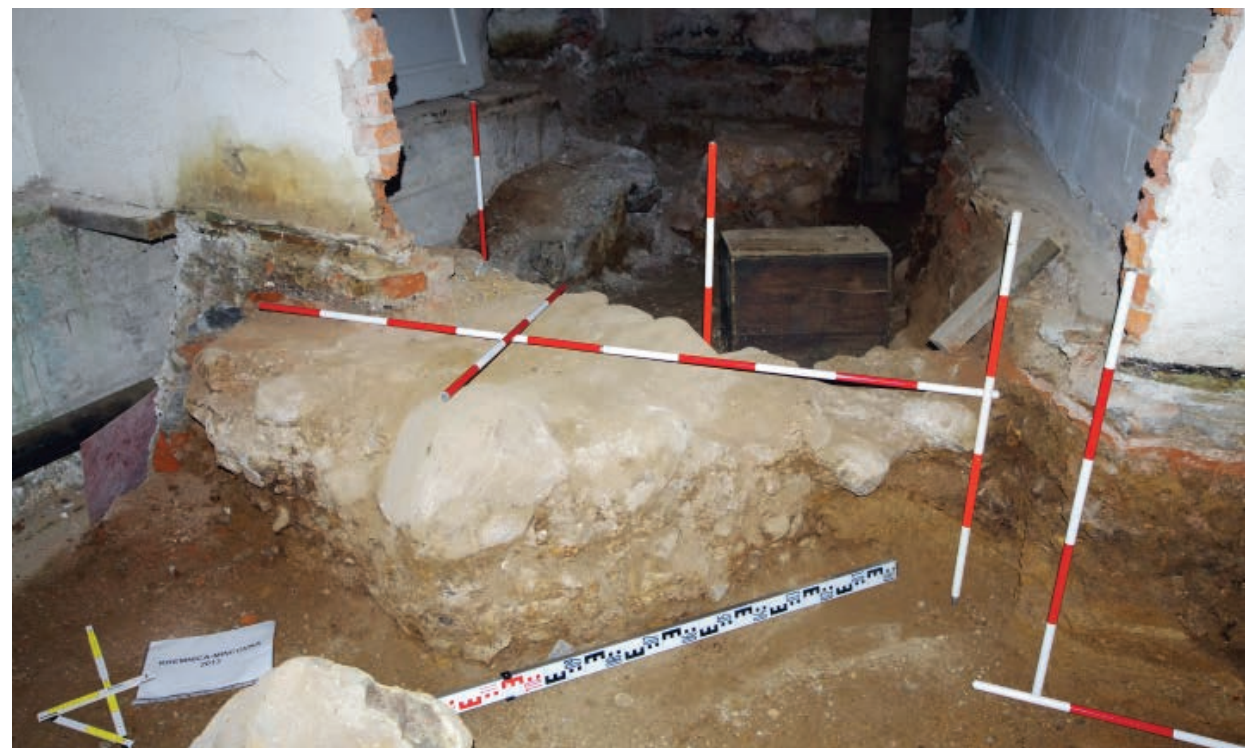

Obr. 12. Kremnica - Mincovňa Kremnica. Výskum v rokoch 2013-2014. Miestnost' A pri pohl’ade z východu. Múr 2 (základové murivo veže barbakanu). Foto $K$. Kučeráková.

Abb. 12. Kremnitz - Kremnitzer Münzhaus. Grabung von 2013-2014. Raum A aus östlicher Richtung. Mauer 2 (Fundamentmauerwerk des Barbakanenturms). Foto K. Kučeráková.

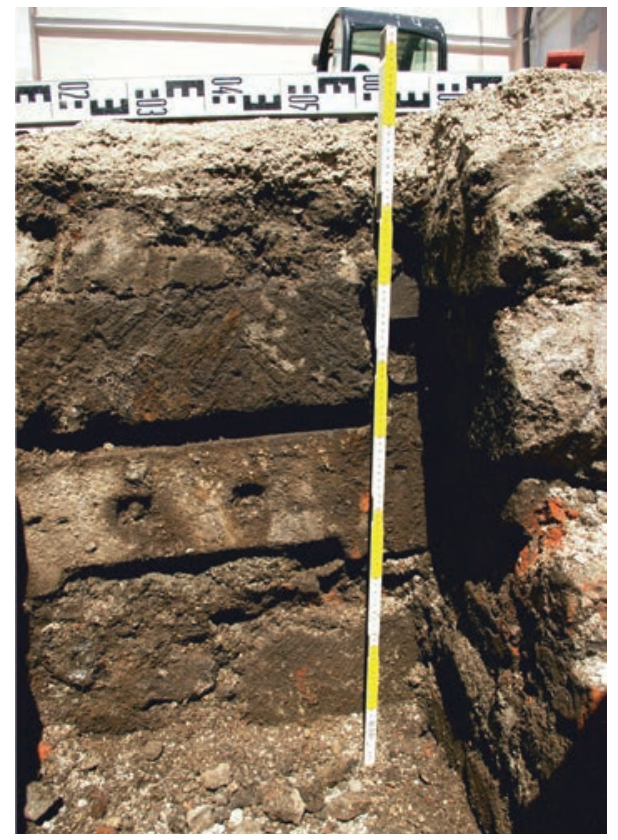

Obr. 13. Kremnica - Mincovňa Kremnica. Výskum v rokoch 2013-2014. Severné nádvorie, sonda pätky 13. Profilované ostenia okien v severnom profile. Foto K. Kučeráková. Abb. 13. Kremnitz - Kremnitzer Münzhaus. Grabung von 2013-2014. Nördlicher Hof, Sondierschnitt von Fuß 13. Profilierte Fensterlaibung im nördlichen Profil. Foto K. Kučeráková. kanalizácie (obr. 14; Beljak-Kučeráková 2010). Počas výkopových prác tu bol okrem hnutel'ných archeologických nálezov odkrytý aj stredoveký múr spájaný vápenatou maltou (objekt 2; obr. 15). Ide o 1,2-1,3 m hrubý objekt, odkrytý do výšky ca $50 \mathrm{~cm}$. Doložil sa v híbke približne 1,6 m od pôvodnej nivelety nádvoria. Nachádza sa 1,8 m západne od východnej línie strednej časti nádvoria. V tejto časti sa híbila kanalizačná ryha SSZ-JJV orientácie. Napriek úzkej ryhe a skromným rozmerom objaveného torza možno konštatovat', že múr mal pôvodne východozápadnú orientáciu. Smerom na východ sa strácal pod východným krídlom mincovne a smerom na západ pod vrstvou makadamu, kde sa jeho pokračovanie nepodarilo doložit'. Je možné, že bol zničený počas výstavby priemyselných zariadení mincovne v druhej polovici 20. storočia. Múr bol založený v žltom ílovitom podloží.

Uvedený objekt sa nachádza na nádvorí tzv. nového komorského dvora, ktorý bol vystavaný pred rokom 1434. Ide o pôvodne jednotraktové budovy zoskupené na stranách uzavretého dvora $\mathrm{v}$ juhovýchodnej časti mincovne. Stredoveký múr odkrytý archeologickým výskumom leží pri murive z obdobia od 16. storočia (najmä okolo roku 1548) až do 17. storočia. 


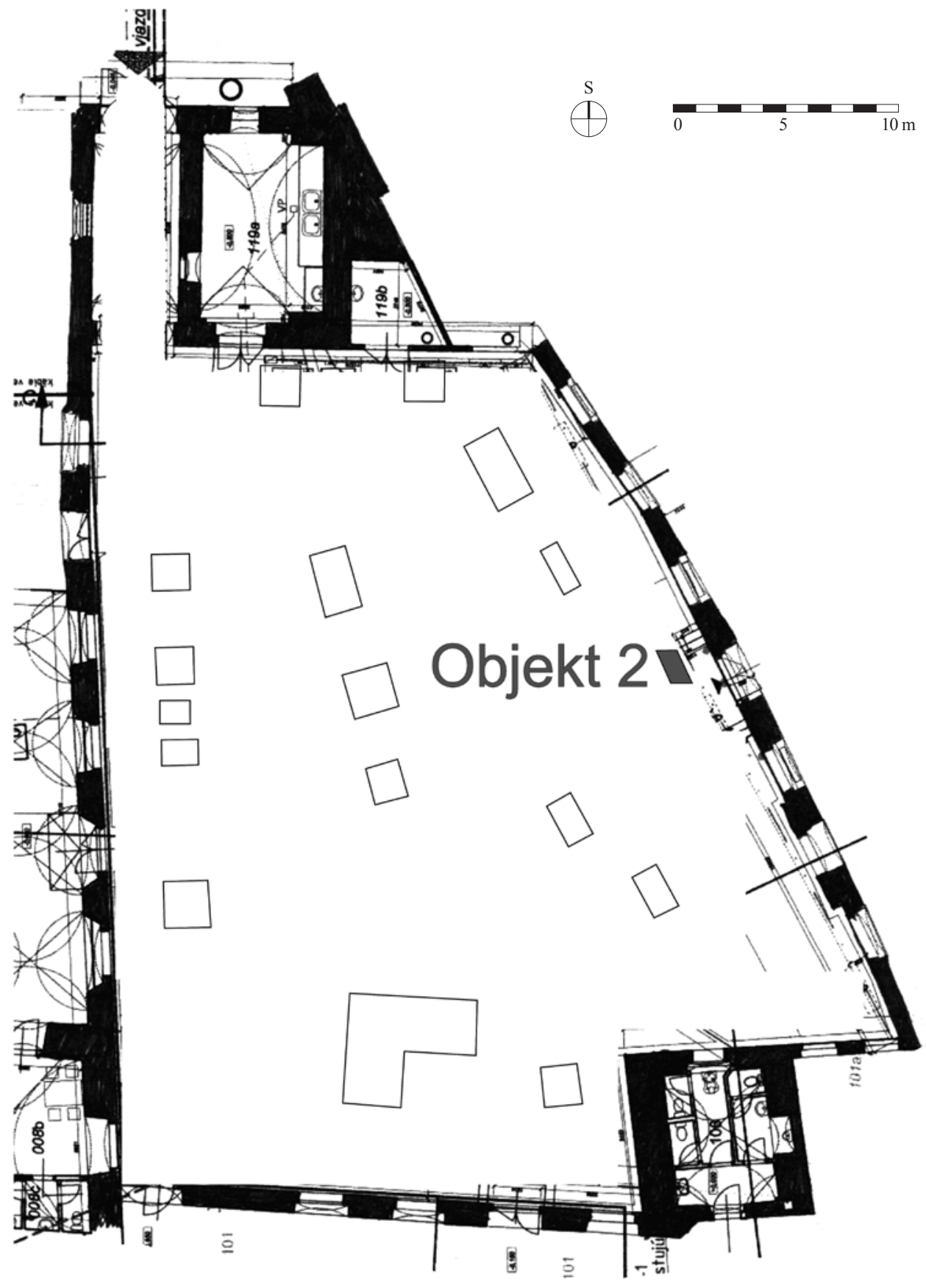

Obr. 14. Kremnica - Mincovňa Kremnica. Výskum v roku 2010. Lokalizácia objektu 2 v priestore tzv. nového komorského dvora. Autor J. Beljak.

Abb. 14. Kremnitz - Kremnitzer Münzhaus. Grabung von 2010. Lokalisierung von Objekt 2 im Bereich des sog. Neuen Kammerhofs. Erstellt von J. Beljak. 


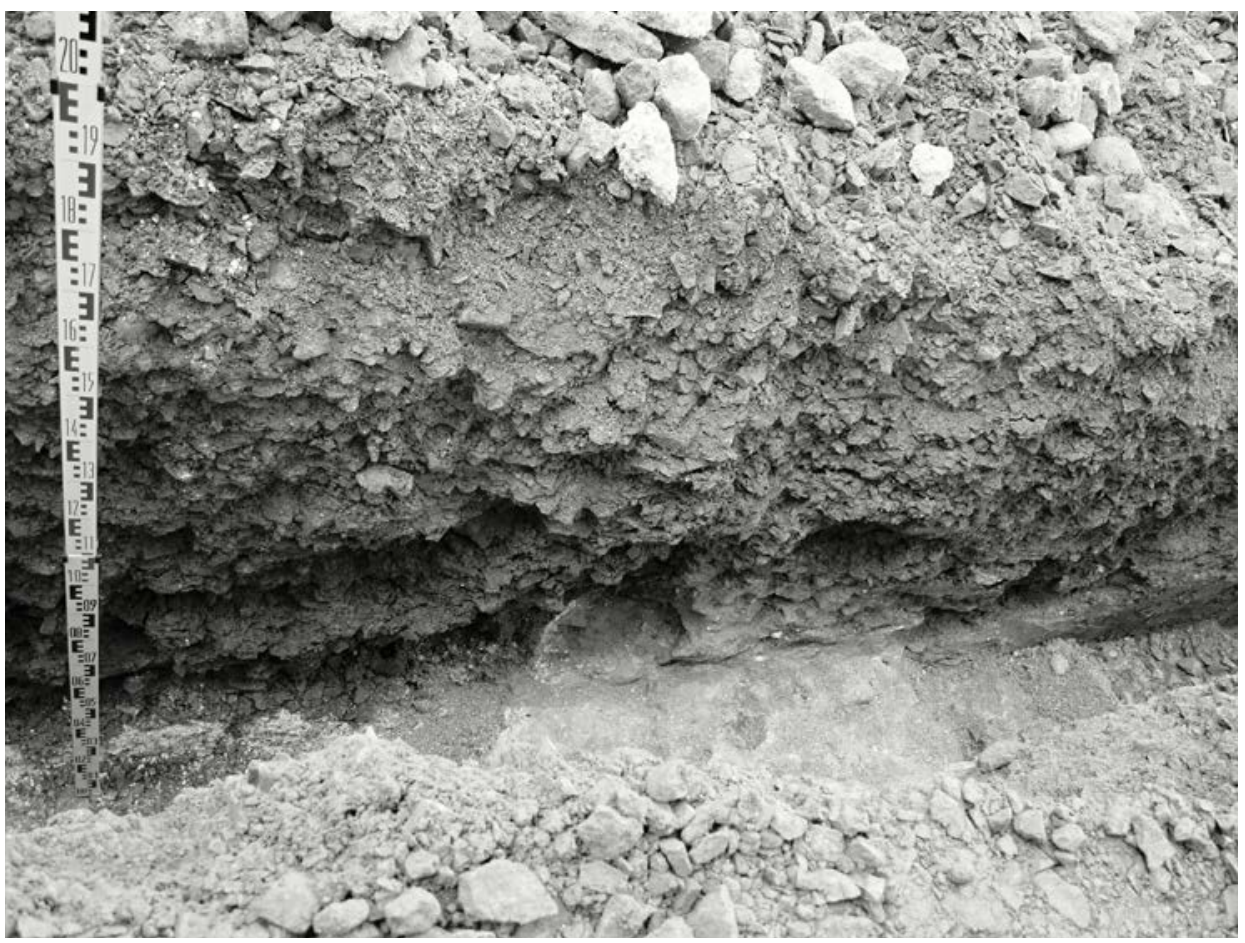

Obr. 15. Kremnica - Mincovňa Kremnica. Výskum v roku 2010. Pohl’ad zo severovýchodu. Objekt 2/2010 v ryhe pre kanalizáciu. Foto J. Beljak.

Abb. 15. Kremnitz - Kremnitzer Münzhaus. Grabung von 2010. Blick von Nordosten. Objekt 2/2010 in der Kanalisationsrinne. Foto J. Beljak.

Čast' východnej línie nádvoria, ležiaca severne od preskúmaného objektu, bola prestavovaná aj v prvej polovici 19. storočia. Južná čast' chodby pozdíž východnej línie dvora bola pristavaná medzi rokmi 1767-1855. V rovnakom období bola uprostred nádvoria vybudovaná rozmerná fontána a vznikol aj priamy prejazd medzi novým komorským dvorom a severným dvorom budovy. Štruktúra architektúry naznačuje jeho stredoveký pôvod, nemožno však celkom vylúčit, že ide o pozostatok z obdobia neskorších prestavieb.

Okrem vyššie uvedeného sa v roku 2010 odkryl v miestnosti v severnom cípe nového komorského dvora opracovaný kamenný blok s takmer pravidelným pôdorysom, ktorý mal na južnej stene pravidelný zárez. Rozmery kameňa boli ca 1,5 × 1,5 × 1,35 m. Vzhl'adom na absenciu akýchkol'vek hnutel’ných nálezov sú jeho datovanie i funkcia otázne.

\section{Záver}

Archeologickým výskumom v Mincovni Kremnica v rokoch 2010 a 2013-2014 sa doložila torzálna stredoveká a novoveká architektúra. Ciel’om bolo interpretovat' jednotlivé objekty v severozápadnej časti stredovekého mestského opevnenia Kremnice. Podarilo sa pritom identifikovat’ základový múr stredovekej fortifikácie, datovanej do prvej štvrtiny 15. storočia. Ide o koncový úsek hradby západne od jeho napojenia na Hornú bránu. V zásype tohto múru sa nachádzala stredoveká keramika. Ďalším objektom, ktorého zvyšky sa podarilo zdokumentovat', je tzv. Horná brána hranolového tvaru. Datuje sa do obdobia výstavby mestského opevnenia. Renesančný barbakan postavený okolo Hornej brány zosilnil obranu prilahlej fortifikácie pravdepodobne v druhej štvrtine 16. storočia. Archeologickým výskumom sa podarilo doložit’ múr západnej línie predbránia v mieste jeho pripojenia na mestskú fortifikáciu a tiež zvyšky veže 
barbakanu. Základy severného múru budovy pristavanej k západnému múru Hornej brány pochádzajú zo stavby, ktorá vznikla po roku 1767. V tomto priestore sa pôvodne nachádzala pravdepodobne bránka pre peších. Ďalšie stredoveké architektúry sa zdokumentovali vo východnej a severnej časti takzvaného nového komorského dvora.

Uvedené torzá, odkryté archeologickým výskumom, boli strhnuté kvôli prestavbe mincovne v rokoch 1882-1889. Objekty továrne pôvodne kopírovali mestské hradby v severozápadnej časti námestia. Pri rozširovaní nové priestory mincovne zabrali pozemok medzi bývalou hradbou a potokom a prekonali pôvodnú líniu mestského opevnenia. $Z$ tohto obdobia sa počas archeologického výskumu doložili takmer vo všetkých miestnostiach východného krídla severného traktu mincovne novoveké objekty.

Na záver by sa autori článku chceli pod’akovat' za dobrú spoluprácu a ústretovost' personálu Mincovne Kremnica.

\section{Literatúra}

BELJAK, J.-KUČERÁKOVÁ, K., 2010: Kremnica, mincovňa - Žiar nad Hronom. Výskumná správa AÚ SAV 17234. Nitra.

- 2014: Kremnica - Mincovňa. Výskumná správa AÚ SAV 18565. Nitra.

DVOŘÁKOVÁ, V.-HUSOVSKÁ, L., 1988: Príspevok k urbanisticko-architektonickému vývoju a ochrane bývalého slobodného královského mesta Kremnica, Monumentorum Tutela 13, 138-164.

FILLOVÁ, L., 1986: Kremnica barbakán, pamiatkový výskum, nepubl. rkp. ulož. v archíve KPÚ Banská Bystrica, sign. T 34.

HAAS KIANIČKKA, D., 2014: Kremnica. Mesto klenotov. Od počiatkov do polovice 17. storočia. Encyklopedický sprievodca dejinami mesta. 1. zväzok. Budmerice.

HORÁK, J., 1965: Kremnická mincovňa. Banská Bystrica.

HOŠŠO, J., 1983: Historickoarcheologický výskum NKP Kremnica-hrad, nálezová správa ulož. v archíve KPÚ Banská Bystrica, sign. T 2026.

- 2007: Výskumná dokumentácia archeologického výskumu na mieste stavby: Rekonštrukcia komunikácie Kutnohorská ulica, Kremnica - v pamiatkovej rezervácii Kremnica, nepubl. rkp. ulož. v archíve KPÚ Banská Bystrica, bez sign.

CHMELÍK, J.-KIANIČKA, D.-KAMHALOVÁ, M., 2005: Mincovňa Kremnica. Stručný sprievodca históriou kremnickej mincovne. Žilina.

KAZIMÍR, Š., a kol., 1978: Kremnická mincovňa. Martin.

KRIŽANOVÁ, Š., 1947: Kremnica. Výpis zo súkromného listu, výskumná správa AÚ SAV v Nitre, č. 256/1947.

LAMOŠ, T., 1969: Vznik a počiatky banského a mincového mesta Kremnice 1328-1430. Banská Bystrica.

MALČEK, R.-KUČERÁKOVÁ, K., 2011: Kremnica. Štefánikovo námestie - kostol, výskumná správa AÚ SAV v Nitre, č. 17434.

MIŇO, M., 2011: Niekol'ko postrehov k fortifikačným prvkom miest stredoslovenskej banskej oblasti Einige Beobachtungen zu Elementen von Befestigungsanlagen mittelalterlicher Bergbaustädte, AH 36, 289-302.

ORIŠKO, Š., 1984: Kremnica. Pamiatková rezervácia. Bratislava.

PAULINYI, O., 1965: Die Edelmetallproduktion der niederungarischen Bergstädte, besonders jene von Schemnitz in der Mitte des 16. Jahrhunderts. In: Nouvelles Études historiques, vol. I, 181-196. Budapest. ŠÁŠKY, L., 1968: Kremnica. Umeleckohistorické pamiatky na Slovensku. Bratislava.

\section{Zusammenfassung}

\section{Die archäologische Grabung im Kremnitzer Münzhaus von 2010-2014}

Kremnitz (Kremnica) wurde am siebzehnten November 1328 als Stadt konstituiert, wobei sich dieses Datum vielmehr noch auf die Gründung der städtischen Münzprägestätte bezieht, die im Laufe ihrer Existenz mehrmals umgebaut wurde und bis heute in Betrieb ist. Größere bauliche Veränderungen hängen mit dem Zeitraum zwischen 1882-1889 zusammen, als das Obere 
Stadttor, die zu diesem gehörende Barbakane sowie ein daran angrenzender Abschnitt der Stadtmauer abgerissen wurde (Abb. 1). Die Überreste der genannten Bauten wurden in den Jahren 2013-2014 freigelegt. Auch im Jahr 2010 erfolgte im Kremnitzer Münzhaus eine archäologische Grabung, deren Durchführung unter der Leitung der Verfasser des vorliegenden Beitrags J. Beljak und K. Kučeráková stand.

Sigismund von Luxemburg verfügte im Jahr 1405, dass Königsstädte Stadtbefestigungen zu errichten hätten. In der Bergbauregion reagierte lediglich Kremnitz auf diese Anregung und ließ die Stadtmauer offenbar in den Jahren 1405-1426 errichten. Die Befestigung besteht aus Bruchsteinen und Flusskiesel städtischer Provenienz und erreicht eine Höhe von $12 \mathrm{~m}$. Von außen wurde sie durch Bäche (südlicher und westlicher Teil) oder durch einen Graben (östlicher Teil) geschützt. Die Stadtmauer wurde nie durch einen Zwinger verstärkt. Die Stadtbefestigung umfasst das Untere, das Obere und das Neusohler Tor. Durch die Befestigung wurde der von 38 mit Häusern bebauten Parzellen umgebene, fast rechteckige Marktplatz umgrenzt.

Während der in den Jahren 2010-2014 durchgeführten archäologischen Grabung konnten im Kremnitzer Münzhaus die Überreste von Objekten freigelegt werden, die Bestandteil der Stadtbefestigung waren. Ein Fundamenttorso der mittelalterlichen Befestigung ist in Raum A belegt (Mauer 5; Abb. 6, 7). Es handelt sich dabei um einen Abschnitt der Stadtmauer westlich von ihrem Anschluss an das Obere Tor, wo sich das Fußgängertor befand (Abb. 4). Die Mauer umgrenzte den nordwestlichen Teil des Münzhauses, wo dessen westlicher und östlicher Flügel zipfelförmig zusammenliefen und sich Futterkammern und ein Holzlager befanden. Der in den Jahren 2013-2014 entdeckte Torso umgrenzte von nordwestlicher Seite her ursprünglich den Stall des Münzhauses. Östlich von der entdeckten Architektur befand sich die zum südlichen Teil des Oberen Tores führende Ausfahrt aus dem zweiten, nördlichen Hof.

Wegen des höheren Verkehrsaufkommens wurde dieser Teil der Befestigung im Jahr 1872 zusammen mit dem Oberen Tor saniert (Abb. 2), was anschließend den 1882-1889 erfolgten Umbau des Werks ermöglichte. Das Obere Tor hatte einen ähnlichen Charakter wie das auch heute noch existierende Untere Tor. Es handelt sich um ein prismenförmiges Turmobjekt mit einem von außen durch ein Fallgitter und von innen durch Tore geschlossenen Durchgang.

Sein Aussehen wurde auf einem Ölgemälde des akademischen Malers Vojtech Angyal, der entschieden gegen den Abriss des Unteren Tors vorging, sowie auf zeitgenössischen Fotografien (Abb. 3, 4) festgehalten. Überreste des Tors wurden bereits durch eine von Jozef Hoššo geleitete archäologische Grabung in der Kutnohorská-Straße belegt. Während der in den Jahren 2013-2014 durchgeführten Grabung wurde der vom Oberen Tor zum nördlichen Zipfel des Gebäudes führende Abschnitt des Stadttores nachgewiesen. Dabei handelt es sich um den nordöstlichen Teil von Mauer 5.

Außer der Verstärkung der Stadtmauer errichtete die Stadt vor dem Unteren und dem Oberen Stadttor noch Renaissancebarbakanen. Sie entstanden in der gefährlichen Zeit der Türkeneinfälle nach der Schlacht bei Mainz.

Turmreste der Barbakane des Oberen Tors wurden bei der Grabung von 2013-2014 nachgewiesen (Mauern 1-3; Abb. 6, 10-12). Da es scheint, dass Mauer 6 (Abb. 6, 7) in Richtung Barbakanentor verlief und zugleich eine ähnliche Bauweise wie der belegte Torso der Barbakane hat (Mauern 1-3), ist es wahrscheinlich, dass sie das Fundamentmauerwerk der westlichen Flucht des Vortors an der Stelle darstellt, an welcher dieses an die Stadtbefestigung angeschlossen war.

Der Blick aus dem Innern dieses Vortors auf die Nordfassade des Oberen Tors ist auf einer zeitgenössischen Fotografie erhalten geblieben (Abb. 3). Auf einer weiteren Fotografie (Abb. 4) sind wahrscheinlich mit dem Abriss des Tors beginnende Arbeiter zu sehen. Darüberhinaus existiert noch eine Fotografie, auf welcher die Abrissarbeiten des Barbakanenturms festgehalten werden (Abb. 5).

Am nordwestlichen, das Münzhaus umgebenden Teil der Stadtbefestigung wurde ein von außen angebautes Gebäude in den westlichen inneren Teil der Barbakane integriert (Abb. 3, 4). Sein Dach fiel schräg von der Westmauer des Oberen Tors nach Westen hin ab und nahm von östlicher Seite her fast dessen ganze Breite ein. Es ist wahrscheinlich, dass das Fundament dieses 
Baus während der Grabung von 2013-2014 in Raum B entdeckt wurde und man es mit Mauer 4 identifizieren kann. Diese stellt das Fundament der Nordmauer des genannten Baus dar, an die ein weiteres Gebäude anschloss.

An der Stelle, an welcher später das durch Mauer 4 belegte Gebäude errichtet worden war, hatte sich höchstwahrscheinlich das Fußgängertor befunden. Dieses Tor konnte jedoch bereits vor dem zwischen 1882 und 1889 erfolgten Umbau des Münzhauses nicht mehr in Betrieb gewesen sein. Man kann festhalten, dass der betreffende Bau nach 1767 errichtet worden war und Ende des 19. Jahrhunderts beim Umbau des Münzhauses verschwand.

Daneben ist es im Jahr 2010 gelungen, eine weitere Torsalarchitektur freizulegen. Dabei handelt es sich um eine Mauer (Objekt 2; Abb. 14, 15) im östlichen Teil des sogenannten neuen Kammerhofs (d.h. um den ältesten Teil des Münzhauses). Die Struktur der Architektur deutet auf einen mittelalterlichen Ursprung hin, jedoch kann insgesamt nicht ausgeschlossen werden, dass es sich dabei um ein Überbleibsel aus der Zeit späterer Umbauten handelt. Darüberhinaus wurde im Jahr 2010 in einem Raum im nördlichen Zipfel des neuen Kammerhofs ein bearbeiteter Steinblock mit fast regelmäßigem Grundriss freigelegt, dessen Datierung vorerst fraglich ist.

Mgr. Kristína Kučeráková, PhD., Archeologický ústav SAV, Vysunuté pracovisko Zvolen, Štúrova 2, SK 96053 Zvolen, Slovenská republika,kristina.kucerakova@savba.sk

PhDr. Ján Beljak, PhD., Archeologický ústav SAV, Vysunuté pracovisko Zvolen, Štúrova 2, SK 96053 Zvolen, Slovenská republika, beljak@savzv.sk 